\title{
Cuidando do Cuidador: Reflexões Sobre o Processo de Trabalho e Repercussões do Cuidado na Saúde dos Agentes Comunitários de Saúde
}

\author{
Gaião, Bárbara Katiene Magno; Lima Filho, Ivo de Andrade; Maciel, Plínia M. de \\ Santana; Sobel, Juliana Figueredo \\ Universidade Federal de Pernambuco — barbaragaiao@gmail.com
}

\begin{abstract}
INTRODUÇÃO: a estratégia de saúde da família (ESF) configura-se como porta de entrada do sistema único de saúde, composta por uma equipe de médico, enfermeiro, auxiliares de enfermagem e agentes comunitários de saúde (ACS), o funcionamento da mesma demanda dessas equipes práticas fundamentadas no viés da assistência integral, entendida por ações de prevenção e promoção de saúde que objetivam a qualidade de vida e cidadania do usuário. no entanto, a operacionalização das ações são obstadas pela falta de insumos, elevadas demandas e problemas na psicodinâmica do trabalho que desta forma precarizam o cenário de trabalho atual, comprometem a qualidade da assistência prestada, além de vulnerabilizar o bem-estar biopsicossocial destes profissionais. Neste cenário da ESF os ACS são responsáveis pela mediação entre os comunitários e equipe de saúde, justificada pelo ato de morar e atuar na mesma comunidade. Porém essa íntima relação poderá repercutir no desempenho ocupacional dos mesmos à medida que o envolvimento pessoal e o desgaste emocional se intensificam, expondo assim a necessidade de cuidado a estes profissionais. OBJETIVO: este trabalho objetiva refletir sobre as repercussões do processo de trabalho no comprometimento da saúde dos ACS e relatar as ações de empoderamento sobre este cuidado. METODOLOGIA: trata-se de um estudo tipo pesquisa-ação realizado com 13 ACS de uma Unidade de Saúde da Família do distrito sanitário IV do município do Recife. Os encontros foram desenhados com base no modelo de grupo operativo, e envolviam a escuta qualificada e acolhedora dos participantes e um olhar terapêutico diante da mesma. Coordenado por um Terapeuta Ocupacional e estudantes desta mesma categoria profissional, os grupos eram realizados semanalmente com duração de uma hora e meia no período de maio de 2011 a dezembro de 2013. RESULTADOS: a ausência do distanciamento entre o papel ocupacional do ACS e o papel de morador da mesma comunidade, a distorção deste papel ocupacional para além das demandas que the são preconizadas e a precarização do trabalho foram os principais questionamentos abordados durante os grupos. Estas implicações confluem de forma significativa para surgimento de comprometimentos físicos, psicológicos e sociais no desempenho ocupacional destes profissionais. Desta forma os agentes foram estimulados a refletirem sobre possíveis resolutividades, diante da troca de saberes e experiências dos mesmos. Também foram direcionados a incorporarem práticas integrativas, de autocuidado, e de lazer nas suas atividades cotidianas para assim proporcionar a continuidade deste cuidado, prevenindo os sintomas de adoecimento físico e mental e promovendo saúde. CONCLUSÕES: Diante do exposto observase a necessidade de investimento nas ações de cuidado ao cuidador, tendo em vista o bemestar biopsicossocial do mesmo e a repercussão deste cuidado na qualidade da assistência oferecida aos usuários dos serviços de saúde.
\end{abstract}

Gaião, Bárbara Katiene Magno; Lima Filho, Ivo de Andrade; Maciel, Plínia M. de Santana; Sobel, Juliana Figueredo. Cuidando do Cuidador: Reflexões Sobre o Processo de Trabalho e Repercussões do Cuidado na Saúde dos Agentes Comunitários de Saúde. In: Anais do Congresso Internacional de Humanidades \& Humanização em Saúde [= Blucher Medical Proceedings, num.2, vol.1]. São Paulo: Editora Blucher, 2014. ISSN 2357-7282

DOI 10.5151/medpro-cihhs-10733 